\title{
Perbandingan Aktivitas Antibakteri Antara Ekstrak Daun Katang-Katang (Ipomoea pes-caprae L.) Dan Minyak Seith Terhadap Pertumbuhan Staphylococcus aureus
}

\author{
Comparison of antibacterial activities between katang-katang leaf extract \\ (Ipomoea pes-caprae L.) and seith oil on the growth of Staphylococcus aureus
}

\author{
Jennifer Vivian Kiriwenno ${ }^{1}$, Melda Yunita ${ }^{2 *}$, Vina Z. Latuconsina ${ }^{2}$ \\ ${ }_{1}$ Mahasiswa Fakultas Kedokteran Universitas Pattimura Ambon \\ 2 Fakultas Kedokteran Universitas Pattimura Ambon \\ Corresponding author: Melda Yunita: Email: meldayunita22@gmail.com \\ Submitted: 30-07-2020 Revised: 30-09-2020 Accepted: 05-10-2020
}

\begin{abstract}
ABSTRAK
Penyakit infeksi merupakan salah satu masalah kesehatan yang dihadapi oleh negara berkembang seperti di Indonesia. Salah satu penyebab infeksi ialah bakteri Staphylococcus aureus. Tanaman katang-katang (Ipomoea pes-caprae L.) dan minyak seith merupakan produk tanaman yang memiliki potensi sebagai agen antibakteri. Penelitian ini bertujuan untuk mengetahui kemampuan dan konsentrasi yang paling efektif dari ekstrak daun katang-katang dan minyak seith dalam menghambat pertumbuhan Staphylococcus aureus. Penelitian ini menggunakan ekstrak daun katang-katang dan minyak seith dalam konsentrasi 10\%, 20\%, 40\%, 60\%, 80\% dan 100\% serta ampisilin sebagai kontrol positif dan aquades sebagai kontrol negatif yang diuji dengan Staphylococcus aureus kemudian diukur zona hambatnya dengan 3 kali pengulangan. Hasil uji menunjukkan rerata zona hambat terbesar terbentuk pada konsentrasi $100 \%(12.0 \mathrm{~mm})$ kemudian diikuti oleh konsentrasi 80\% (7.66 mm), 60\% (0 mm), 40\% (0 mm), 20\% (0 mm), dan $10 \%(0 \mathrm{~mm})$ pada ekstrak daun katang-katang sedangkan pada minyak seith tidak terbentuk zona hambat untuk semua konsentrasi. Data hasil pengamatan dianalisis menggunakan one-way ANOVA dan uji lanjut menggunakan Bonferroni Test menunjukkan nilai signifikansi $0.000(\mathrm{p}<0.05)$. Hal ini berarti secara statistik, hasil penelitian ini menunjukkan perbedaan yang signifikan. Pemberian ekstrak daun katang-katang memiliki potensi sebagai agen antibakteri terhadap pertumbuhan Staphylococcus aureus dibandingkan minyak seith.
\end{abstract}

Kata kunci: Aktivitas antibakteri; Daun katang-katang (Ipomoea pes-caprae L.); Minyak seith; Staphylococcus aureus

\begin{abstract}
Infectious disease is one of the health problems faced by developing countries like Indonesia. One cause of the infection is Staphylococcus aureus. Katang-katang (Ipomoea pes-caprae L.) and seith oil are plant products that have the potential as antibacterial agents. The aim of this study was to determine the ability and effective concentration of katang-katang leaf extract and seith oil in inhibiting the growth of Staphylococcus aureus. This study used katang-katang leaf extract and seith oil as the experimental group with the concentration level of 10\%, 20\%, 40\%, 60\%, 80\% and 100\%. The standard in this study was ampicillin as the positive control and aquades as the negative control. The experimental group and the standard are tested on Staphylococcus aureus where the treatments were repeated three times for the experimental group. The results showed that the largest inhibitory zone of katang-katang leaf extract was found at 100\% concentration level $(12.0 \mathrm{~mm})$ then followed by $80 \%$ concentration level $(7.66 \mathrm{~mm}), 60 \%(0 \mathrm{~mm}), 40 \%(0 \mathrm{~mm}), 20 \%(0 \mathrm{~mm})$, and 10\% (0 mm). Meanwhile, the inhibitory zone was not found at any concentration levels of seith oil. Data from the observation were analyzed by using one-way (ANOVA) and tested by using the Bonferroni test which showed a significant value of 0,000 ( $p$ <0.05). It means that the result of this study has a statistically significant difference. Therefore, it can be concluded that katang-katang leaf extract has the potential to be used as an antibacterial agent against the growth of Staphylococcus aureus compared to seith oil.
\end{abstract}

Keywords: Antibacterial activity; Katang-katang leaf (Ipomoea pes-caprae L.); Seith oil; Staphylococcus aureus. 


\section{PENDAHULUAN}

Penyakit infeksi merupakan salah satu masalah kesehatan yang dihadapi oleh negara berkembang seperti di Indonesia. Menurut Afifurahman et al (2014), Salah satu penyebab infeksi di Indonesia yaitu Methicilin-Resistant Staphylococcus aureus (MRSA) dengan prevalensi cukup tinggi $(23,5 \%)$. Penyakit infeksi dapat terjadi di seluruh bagian tubuh, salah satunya di kulit. Mikroorganisme yang menempati kulit tanpa menimbulkan penyakit pada inang disebut dengan flora normal. Salah satu flora normal pada kulit adalah Staphylococcus aureus. Namun, sistem imun yang melemah dapat memicu infeksi serius dari Staphylococcus aureus (Afifurrahman et al., 2014). Beberapa penyakit yang dapat timbul akibat infeksi Staphylococcus aures adalah impetigo, folukulitis, erisipelas, dan selulitis (Rumopa et al., 2016).

Berbagai cara dilakukan untuk pengobatan penyakit infeksi, baik secara modern seperti antibiotik maupun secara tradisional seperti menggunakan tanaman. Pengobatan dengan antibiotik dianjurkan untuk penyakit yang disebabkan oleh bakteri. Perkembangan sifat resistensi bakteri tersebut diketahui berhubungan dengan penggunaan antibiotik yang kurang tepat dan perubahan spektrum antibiotik yang digunakan dalam pengobatan (Aziz et al., 2016). Bakteri Staphylococcus aureus memiliki kemampuan adaptasi yang luar biasa sehingga dapat resisten terhadap banyak antibiotik (Afifurrahman et al., 2014). Oleh karena itu, pengobatan dengan sumber alami perlu dilakukan. Salah satunya dengan pemanfaatan pengobatan tradisional dari tanaman.

Penggunaan obat tradisional direkomendasikan oleh World Health Organization (WHO) dalam pemeliharaan kesehatan masyarakat, pencegahan, dan pengobatan penyakit, terutama untuk penyakit kronis dan penyakit degeneratif. Obat tradisional banyak diminati karena mudah didapat di sekitar tempat tinggal dan secara ekonomi lebih terjangkau bila dibandingkan dengan obat dan pengobatan modern. Selain itu, obat-obat tradisional relatif aman karena tidak dicampur dengan bahan kimia sehingga tidak memiliki efek samping seperti halnya obatobatan modern (Nisfiyanti, 2012).

Di daerah Maluku, salah satu pengobatan tradisional yang dikenal untuk mengobati infeksi topikal yaitu dengan tumbuhan katangkatang dan minyak seith. Tumbuhan katangkatang (Ipomoea pescaprae) merupakan tumbuhan khas daerah pantai (Andayani et al., 2018). Masyarakat sering menggunakan tumbuhan katang-katang untuk mengobati infeksi, meredakan nyeri dan sebagai antioksidan. Menurut penelitian Hafizah (2014), daun katang-katang memiliki kandungan alkaloid, flavonoid, tannin, steroid, saponin, terpenoid, dan antroquinon sehingga senyawasenyawa tersebut berfungsi sebagai antimikroba dan merangsang pertumbuhan sel baru pada luka (Saraung et al., 2018).

Selain tumbuhan katang-katang, minyak seith juga menjadi pilihan pengobatan tradisional. Sesuai namanya, minyak seith merupakan produk olahan masyarakat Desa Seith, Kecamatan Leihitu, Kabupaten Maluku Tengah, Provinsi Maluku. Masyarakat desa Seith menggunakan minyak seith untuk mengobati infeksi dan luka. Minyak seith mengandung berbagai sari tanaman di dalamnya seperti kulit manggis (Garcinia mangostana L.), jahe (Zingiber officinale R.), cengkih (Syzygium aromaticum), ekstrak biji pala (Myristica fragrans $\mathrm{H}$.), dan kencur (Kaempferia galangal). Gansareng et al (2018), telah membuktikan buah pala sebagai salah satu komponen dalam minyak seith, memiliki aktivitas antibakteri terhadap beberapa bakteri spesifik. Namun, penelitian mengenai minyak seith dalam satu komponen belum pernah dilakukan.

Berdasarkan uraian dan data-data terkait banyaknya kasus infeksi, dampak resistensi, dan belum pernahnya diteliti mengenai aktivitas antibakteri ekstrak daun katang-katang dan minyak seith terhadap Staphylococcus aureus, maka peneliti tertarik untuk melakukan pengujian menggunakan pengobatan tradisional untuk melihat aktivitas antibakteri dari ekstrak daun katang-katang dan minyak seith terhadap pertumbuhan Staphylococcus aureus.

Penelitian ini bertujuan untuk mengetahui kemampuan ekstrak daun katangkatang dan minyak seith dalam menghambat pertumbuhan Staphylococcus aureus.

\section{METODOLOGI \\ Objek Penelitian}

Penelitian ini menggunakan ekstrak daun katang-katang (Ipomoea pes-caprae L.) dan minyak seith dalam konsentrasi 10\%, 20\%, 
40\%, 60\%, 80\% dan 100\% dalam 3 kali pengulangan pada perlakuan serta ampisilin sebagai kontrol positif dan aquades sebagai kontrol negatif yang diuji dengan Staphylococcus aureus kemudian diukur zona hambatnya.

\section{Instrumen Penelitian}

Alat-alat yang digunakan dalam penelitian ini adalah autoklaf, neraca analitik ohaus, magnetic stirrer, gelas erlenmeyer, lampu bunsen, jarum ose, cawan petri, gelas ukur 100 $\mathrm{ml}$, rak tabung reaksi, tabung reaksi, plastik wrap, allumunium foil, mikropipet, mistar, kertas cakram yang berdiameter $7 \mathrm{~mm}$, rotatory evaporator vacuum. Bahan-bahan yang digunakan dalam penelitian adalah daun katang-katang yang diperoleh dari Pesisir Pantai Desa Galala dan kemudian diekstraksi dan juga minyak seith yaitu produk lokal yang diperoleh dari desa Seith, media nutrient agar, tween 80, aquades (sebagai kontrol negatif dan pengencer konsentrasi), dan antibiotik ampisilin (sebagai kontrol positif).

\section{Prosedur Penelitian \\ Persiapan tumbuhan}

Daun katang-katang (Ipomoea pes-caprae L.) sebanyak $1 \mathrm{~kg}$ disortasi dengan membuang daun rusak, tidak segar, kuning, dan kemudian dicuci dengan air bersih. Setelah dicuci, daun ditiriskan (Bramantio, 2018).

\section{Proses pembuatan ekstrak}

Sebelum dilakukan proses ekstraksi daun katang-katang dijemur selama 2 hari di bawah sinar matahari. Kemudian hasilnya dihaluskan dengan cara diblender kering sampai menjadi bubuk dan dimasukkan kedalam wadah ekstrakstor (erlenmeyer). Kedalam erlenmeyer ditambahkan ethanol sebagai larutan pengekstrak sampai bubuk daun terendam sempurna. Larutan bersama bubuk daun diaduk selama beberapa menit kemudian didiamkan (dimaserasi) pada suhu ruangan selama 1 hari. Hasil maserasi disaring dengan kertas saring. Hasil penyaringan yang didapat dimasukkan kedalam labu evaporator buchi dan dilakukasi evaporasi pada suhu $45^{\circ} \mathrm{C}$ sampai hasil yang diperoleh adalah bahan aktif yang bebas pelarut. Hasil evaporasi berupa gel dipindahkan kedalam wadah penyimpanan (botol) ditutup dengan kertas saring dan dibiarkan pada suhu ruang selama sehari (Laboratorium Kimia Dasar
Jurusan Kimia Fakultas Matematika dan Ilmu Pengetahuan Alam Universitas Pattimura Ambon, 2019).

\section{Pembuatan Konsentrasi}

Untuk membuat beberapa stok konsentrasi ekstrak dari daun katang-katang (Ipomoea pes-caprae L.) dan minyak seith yang diinginkan, digunakan rumus kalkulasi dosis obat yaitu sebagai berikut (Bramantio, 2018):

$$
\mathrm{Vn} \times \mathrm{Cn}=\mathrm{Vs} \times \mathrm{Cs}
$$

Keterangan: Vs: volume stok yang akan diambil; Cs: Konsentasi stok (100\%); Vn: volume untuk membuat konsentrasi yang diharapkan (5 ml); $\mathrm{Cn}$ : Konsentrasi yang diharapkan $(10 \%, 20 \%$, $40 \%, 60 \%, 80 \%$ dan 100\%)

\section{Ekstrak daun katang-katang konsentrasi 10\%} Dibuat dengan cara melarutkan $0,5 \mathrm{ml}$ dari ekstrak yang ditambah dengan 4,5 ml aquadest steril hingga volumenya mencapai 5 $\mathrm{ml}$.

Ekstrak daun katang-katang konsentrasi 20\% Dibuat dengan cara melarutkan $1 \mathrm{ml}$ dari ekstrak yang ditambah dengan $4 \mathrm{ml}$ aquadest steril hingga volumenya mencapai $5 \mathrm{ml}$.

Ekstrak daun katang-katang konsentrasi 40\% Dibuat dengan cara melarutkan $2 \mathrm{ml}$ dari ekstrak yang ditambah dengan $3 \mathrm{ml}$ aquadest steril hingga volumenya mencapai $5 \mathrm{ml}$.

Ekstrak daun katang-katang konsentrasi 60\% Dibuat dengan cara melarutkan $3 \mathrm{ml}$ dari ekstrak yang ditambah dengan $2 \mathrm{ml}$ aquadest steril hingga volumenya mencapai $5 \mathrm{ml}$.

Ekstrak daun katang-katang konsentrasi 80\% Dibuat dengan cara melarutkan $4 \mathrm{ml}$ dari ekstrak yang ditambah dengan $1 \mathrm{ml}$ aquadest steril hingga volumenya mencapai $5 \mathrm{ml}$.

Ekstrak daun katang-katang konsentrasi 100\% Dibuat dengan cara melarutkan $5 \mathrm{ml}$ dari ekstrak dan tidak ditambah dengan aquadest steril.

Minyak seith konsentrasi 10\%

Dibuat dengan cara melarutkan $0,5 \mathrm{ml}$ dari minyak seith yang ditambah dengan 4,475 ml aquadest steril dan ditambah dengan 0,025 tween 80 hingga volumenya mencapai $5 \mathrm{ml}$. 


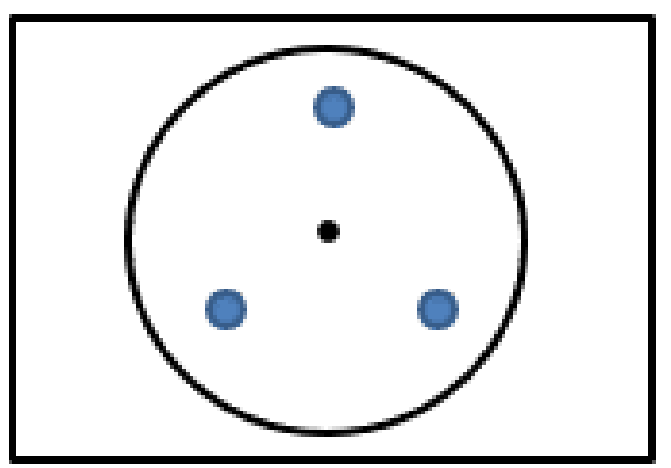

Gambar 1. Model peletakkan kertas cakram pada cawan petri (Patel et al., 2019)

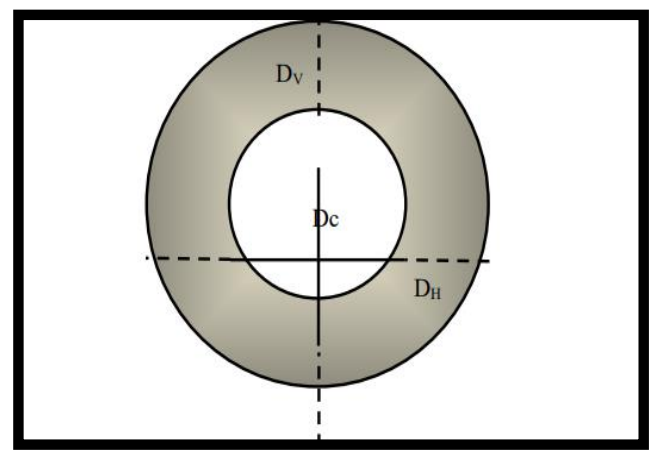

Gambar 2. Pengukuran diameter zona hambat (Toy et al., 2015)

Minyak seith konsentrasi 20\%

Dibuat dengan cara melarutkan $1 \mathrm{ml}$ dari minyak seith yang ditambah dengan $3,975 \mathrm{ml}$ aquadest steril dan ditambah dengan 0,025 tween 80 hingga volumenya mencapai $5 \mathrm{ml}$.

Minyak seith konsentrasi $40 \%$

Dibuat dengan cara melarutkan $2 \mathrm{ml}$ dari minyak seith yang ditambah dengan 2,975 ml aquadest steril dan ditambah dengan 0,025 tween 80 hingga volumenya mencapai $5 \mathrm{ml}$.

Minyak seith konsentrasi $60 \%$

Dibuat dengan cara melarutkan $3 \mathrm{ml}$ dari minyak seith yang ditambah dengan 1,975 ml aquadest steril dan ditambah dengan 0,025 tween 80 hingga volumenya mencapai $5 \mathrm{ml}$.

Minyak seith konsentrasi 80\%

Dibuat dengan cara melarutkan $4 \mathrm{ml}$ dari minyak seith yang ditambah dengan $0,975 \mathrm{ml}$ aquadest steril dan ditambah dengan 0,025 tween 80 hingga volumenya mencapai $5 \mathrm{ml}$.
Minyak seith konsentrasi $100 \%$

Dibuat dengan cara melarutkan $5 \mathrm{ml}$ dari minyak seith yang tidak ditambah dengan aquadest steril maupun tween 80 .

\section{Sterilisasi alat}

Alat yang digunakan pada proses uji daya antibakteri dicuci bersih kemudian dikeringkan dan disterilkan dalam autoklaf pada suhu $121^{\circ} \mathrm{C}$ selama 20 menit (Bramantio, 2018).

\section{Pembuatan media}

Media nutrient agar ditimbang sebanyak 2 gram pada neraca analitik dan dilarutkan dalam aquades $100 \mathrm{ml}$ (perhitungan jumlah mengacu pada takaran yang tertera pada kemasan). Aduk hingga serbuk larut menggunakan magnetic stirrer. Kemudian disterilisasi dengan autoklaf dengan suhu $121^{\circ} \mathrm{C}$ selama 20 menit. Setelah itu dituang sebanyak $10 \mathrm{ml}$ nutrient agar dalam cawan petri steril (Fatisa, 2013). 


\section{Pembuatan stok kerja}

Sebanyak satu

Staphylococcus aureus diambil

menggunakan jarum ose steril, lalu ditanamkan pada nutrient agar miring dengan cara menggores, setelah itu diinkubasi dalam inkubator pada suhu $37^{\circ} \mathrm{C}$ selama 24 jam (Fatisa, 2013).

\section{Uji antibakteri}

Diambil satu koloni bakteri Staphylococcus aureus dengan menggunakan jarum ose steril, lalu ditanamkan pada nutrient agar di cawan petri. Kemudian kertas cakram direndam selama \pm 15 menit dalam aquades steril masing-masing konsentrasi ekstrak daun katang-katang dan minyak seith (Hidayat et al., 2015). Kemudian kertas cakram diletakan pada tiap cawan petri dan diatur jarak tertentu secara teratur agar tidak terjadi overlapping zona hambat yang terbentuk. Kertas cakram yang diletakkan memiliki jarak minimal $24 \mathrm{~mm}$ dari pusat kertas cakram dengan jarak masingmasing cakram minimal $3 \mathrm{~cm}$ (Patel et al., 2019). Setelah penempatan jarak kemudian diberi label (Hafizah, 2014). Pada salah satu petri diletakan kertas cakram antibiotik ampisilin sebagai kontrol positif dan kertas cakram yang telah direndam dalam aquades sebagai kontrol negatif. Perlakuan uji antibakteri ekstrak daun katang-katang (Ipomoea pes-caprae L.) dan minyak seith terhadap Staphylococcus aureus diulang sebanyak $3 \mathrm{x}$ replikasi. Sedangkan pengujian kontrol positif (ampisilin) dan negatif (aquades) dilakukan sebanyak 1x.

\section{Pengukuran daya hambat}

Pengamatan dilakukan setelah 24 jam masa inkubasi. Petunjuk kepekaan bakteri terhadap bahan antibakteri yang digunakan sebagai bahan uji dilihat dari zona bening sekitar kertas cakram dan dinyatakan dengan luas zona hambat serta diukur menggunakan penggaris untuk menentukan diameter vertikal dan diameter horizontal dengan satuan $\mathrm{mm}$ (Toy et al., 2015). Pengulangan uji antibakteri ekstrak daun katang-katang (Ipomoea pescaprae L.) dan minyak seith terhadap Staphylococcus aureus dilakukan sebanyak 3 kali replikasi.

Diameter zona hambat diukur dengan rumus : (Diameter Vertikal-Diameter Cakram)+(Diameter Horisontal-Diameter Cakram)/2 (Toy et al., 2015).
Zona hambat yang terbentuk dikategorikan dalam beberapa kategori berdasarkan besarnya diameter ( $\mathrm{mm}$ ) yaitu; lemah ( $\leq 5 \mathrm{~mm})$, sedang (6-10 mm), kuat (11-20 $\mathrm{mm}$ ), dan sangat kuat ( $\geq 21 \mathrm{~mm}$ ) (Repi et al., 2016).

\section{Analisis Data}

Metode analisis yang digunakan dalam penelitian ini adalah one way analysis of variance (ANOVA) untuk menguji perbedaan antara sejumlah rerata nilai diameter zona hambat dengan cara membandingkan variansinya $(\mathrm{p}<0.05)$. Uji lanjut dilakukan menggunakan Bonferroni Test dengan taraf kepercayaan 95\%.

\section{HASIL DAN PEMBAHASAN}

Hasil pengukuran diameter zona hambat pada kontrol positif menunjukkan adanya zona hambat sebesar 4,50 mm yang termasuk dalam kategori lemah, sedangkan pada kontrol negatif tidak terbentuk zona hambat di sekitar kertas cakram. Hasil pengukuran kontrol positif dan kontrol negatif terhadap pertumbuhan Staphylococcus aureus dapat dilihat pada Gambar 3.

Pada penelitian ini, ampisilin digunakan sebagai kontrol positif. Ampisilin bersifat bakterisida yang dihasilkan dari penghambatan sintesis dinding sel dan dimediasi melalui pengikatan ampisilin ke satu atau lebih Penisilin binding proteins (PBP). Ampisilin menimbulkan efek autolitik bakteri dengan menghambat PBP sehingga terjadi gangguan pada peptidoglikan yang berfungsi untuk mempertahankan integritas dinding sel (finnah et al., 2017). Aktivitas antibakteri yang lemah dari ampisilin dapat disebabkan oleh Staphylococcus aureus yang mulai resisten terhadap ampisilin karena memproduksi beta laktamase yang dapat memecah cincin beta laktam sehingga antibiotik ampisilin menjadi tidak aktif (Triana, 2014).

Pada penelitian ini, ekstrak daun katangkatang diuji menggunakan konsentrasi $100 \%$, $80 \%, 60 \%, 40 \%, 20 \%$, dan $10 \%$. Hasil penelitian menunjukkan rerata zona hambat terbesar terbentuk pada konsentrasi $100 \%(12,0 \mathrm{~mm})$ kemudian diikuti oleh konsentrasi $80 \%(7,66$ $\mathrm{mm}), 60 \%$ (0 mm), 40\% (0 mm), 20\% (0 mm), dan $10 \%$ (0 mm) (Gambar 4).

Terbentuknya zona hambat di sekitar kertas cakram membuktikan bahwa ekstrak daun katang-katang memiliki aktivitas antibakteri terhadap Staphylococcus aureus. 


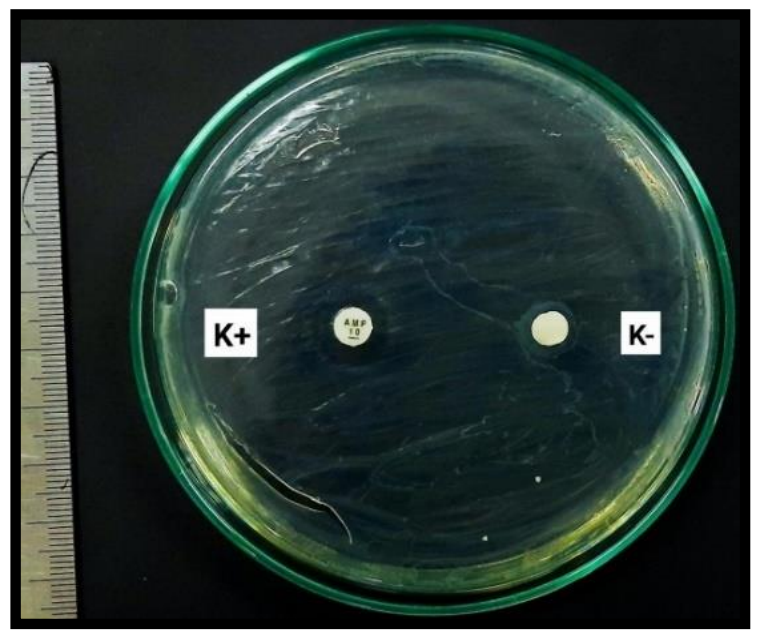

Gambar 3. Kontrol positif dan kontrol negatif

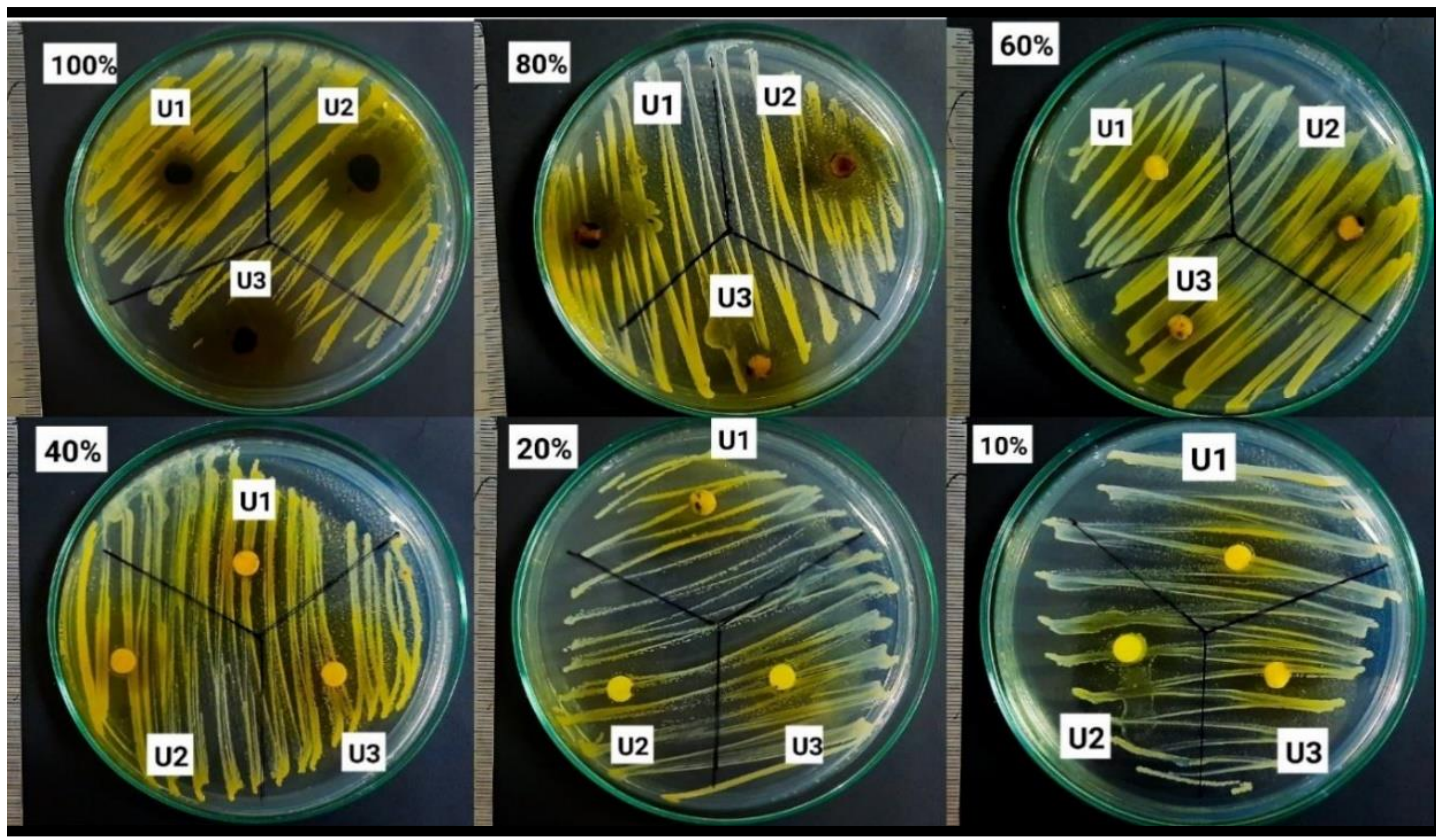

Gambar 4. Hasil uji aktivitas antibakteri ekstrak daun katang-katang terhadap pertumbuhan S.aureus.

Semakin tinggi konsentrasi ekstrak maka zona hambat terhadap bakteri yang terbentuk juga semakin besar. Aktivitas antibakteri disebabkan oleh adanya suatu zat atau senyawa antibakteri yang dapat menghambat pertumbuhan bakteri atau menyebabkan kematian bakteri dengan beberapa mekanisme. Hasil penelitian ini didukung oleh penelitian serupa dari Hafizah (2014) dimana hasil penelitiannya menunjukkan bahwa ekstrak daun katangkatang dengan konsentrasi 100\% memiliki aktivitas antibakteri terhadap Staphylococcus aureus sebesar $11,0 \mathrm{~mm}$. Respon zona hambat yang terbentuk terhadap Staphylococcus aureus mengindikasikan kandungan metabolit sekunder yang dimiliki oleh ekstrak daun katang-katang. Kandungan senyawa aktif dari daun katang-katang (Ipomoea pes-caprae L.) yang berperan sebagai agen antibakteri diantaranya adalah terpenoid, steroid, saponin, tannin, dan flavonoid. Penelitian oleh Hafizah menguji daya hambat ekstrak daun katangkatang terhadap S.aureus dan tidak dibandingkan dengan perlakuan yang lain 


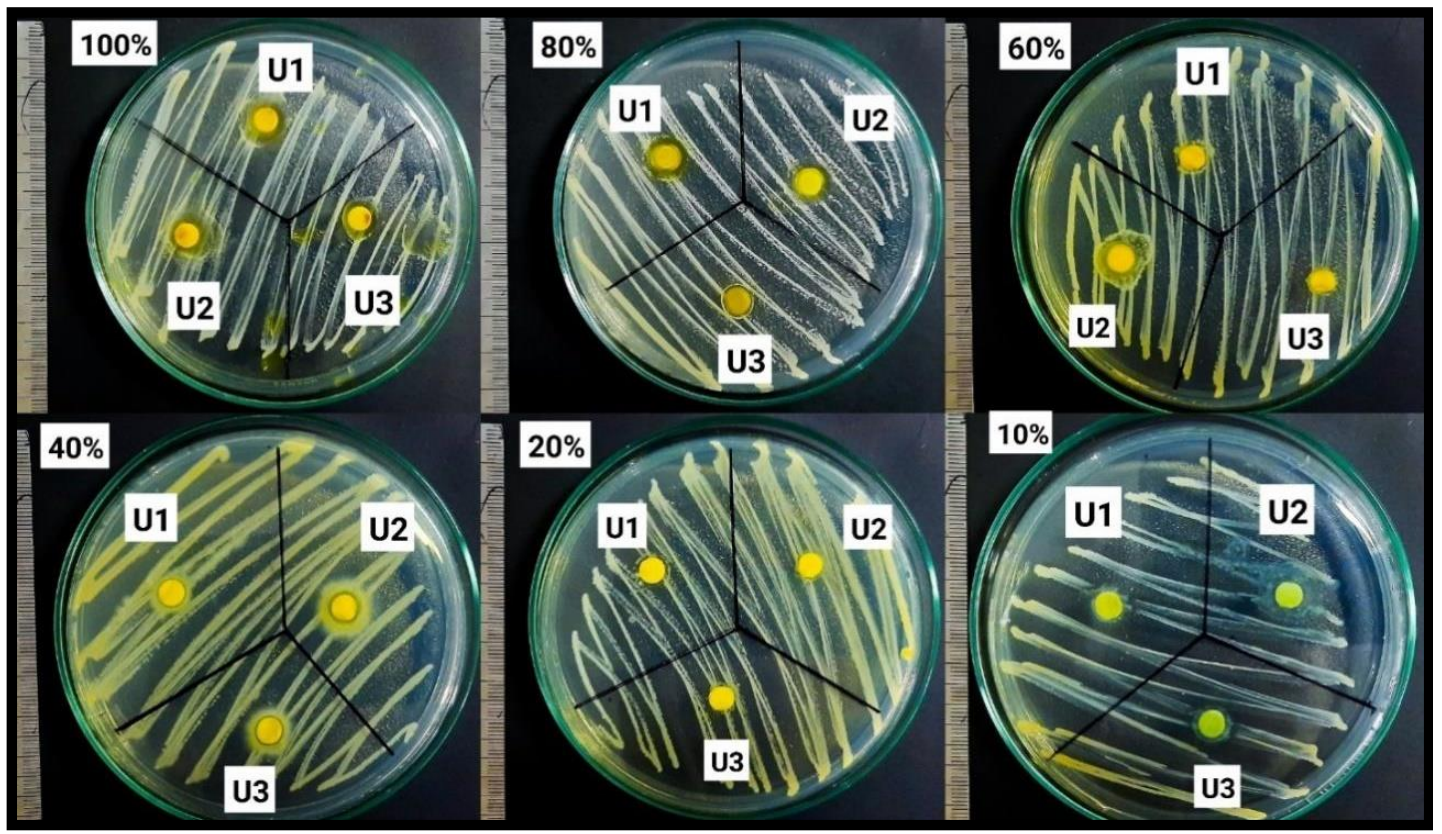

Gambar 5. Hasil uji aktivitas antibakteri minyak seith terhadap pertumbuhan Staphylococcus aureus

Tabel I. Rerata diameter zona hambat untuk masing-masing konsentrasi ekstrak daun katang-katang dan minyak seith dengan 3 kali replikasi pada perlakuan dan 1 kali pengulangan pada kontrol.

\begin{tabular}{|c|c|c|c|c|c|c|}
\hline \multirow{3}{*}{ Konsentrasi } & \multicolumn{6}{|c|}{ Kelompok perlakuan } \\
\hline & \multicolumn{3}{|c|}{$\begin{array}{l}\text { Ekstrak daun katang-katang } \\
\text { (Ipomoea pes-caprae L.) }\end{array}$} & \multicolumn{3}{|c|}{ Minyak seith } \\
\hline & $\begin{array}{c}\text { Rerata zona } \\
\text { hambat } \\
(\mathrm{mm})\end{array}$ & $\begin{array}{l}\text { Standar } \\
\text { deviasi }\end{array}$ & $\begin{array}{l}\text { Kategori } \\
\text { diameter }\end{array}$ & $\begin{array}{c}\text { Rerata zona } \\
\text { hambat } \\
(\mathrm{mm})\end{array}$ & $\begin{array}{c}\text { Standar } \\
\text { deviasi }\end{array}$ & $\begin{array}{l}\text { Kategori } \\
\text { diameter }\end{array}$ \\
\hline $10 \%$ & 0 & 0 & Tidak ada & 0 & 0 & Tidak ada \\
\hline $20 \%$ & 0 & 0 & Tidak ada & 0 & 0 & Tidak ada \\
\hline $40 \%$ & 0 & 0 & Tidak ada & 0 & 0 & Tidak ada \\
\hline $60 \%$ & 0 & 0 & Tidak ada & 0 & 0 & Tidak ada \\
\hline $80 \%$ & 7,66 & 5,10 & Sedang & 0 & 0 & Tidak ada \\
\hline \multirow[t]{3}{*}{$100 \%$} & 12,00 & 5,67 & Kuat & 0 & 0 & Tidak ada \\
\hline & \multicolumn{6}{|c|}{ Kelompok kontrol } \\
\hline & \multicolumn{3}{|c|}{ Kontrol positif } & \multicolumn{3}{|c|}{ Kontrol positif } \\
\hline Konsentrasi & $\begin{array}{c}\text { Rerata zona } \\
\text { hambat } \\
(\mathrm{mm})\end{array}$ & Kategor & diameter & $\begin{array}{r}\text { Rerata zona } \\
\text { (mm }\end{array}$ & hambat & $\begin{array}{l}\text { Kategori } \\
\text { diameter }\end{array}$ \\
\hline $\begin{array}{c}10 \% \\
20 \% \\
40 \% \\
60 \% \\
80 \% \\
100 \%\end{array}$ & 4,50 & & nah & 0 & & Tidak ada \\
\hline
\end{tabular}


Tabel II. Hasil analisis data diameter zona hambat

\begin{tabular}{lll}
\hline F & Sig. & Tingkat kepercayaan (\%) \\
\hline 10,0 & 0,000 & 0,05 \\
\hline
\end{tabular}

Tabel III. Uji homogenitas data

\begin{tabular}{cc}
\hline Levene statistic & Sig. \\
\hline 12,554 & 0,000 \\
\hline
\end{tabular}

sehingga berbeda dengan penelitian ini (Hafizah, 2014).

Dengan konsentrasi yang sama, minyak seith juga diuji kemampuannya dalam menghambat pertumbuhan Staphylococcus aureus. Hasil penelitian menunjukkan tidak terbentuk zona hambat pada semua konsentrasi (Gambar 5). Hal ini mengindikasikan bahwa minyak seith tidak memiliki aktivitas antibakteri terhadap Staphylococcus aureus. Tidak adanya aktivitas antibakteri dari minyak seith dapat disebabkan oleh beberapa faktor, seperti minyak mudah rusak oleh adanya suhu yang panas maupun bahan aktif yang menguap sehingga mengurangi aktivitas antibakteri minyak. Penyulingan pada tekanan dan suhu yang terlalu tinggi akan menguraikan komponen kimia minyak, dan dapat mengakibatkan proses resinifikasi minyak (Nugraheni et al., 2016). Faktor lainnya ialah pelarut yang mampu merusak solut atau residu minyak atsiri yang mengandung fraksi ester akan terhidrolisis karena adanya air dan panas, serta komponen minyak yang larut dalam air tidak dapat diekstraksi (Ariyani et al., 2017). Minyak seith mengandung lima komponen sari tanaman, yaitu pala, cengkih, jahe, manggis, dan kencur. Hasil penelitian Undri et al (2013) menunjukkan bahwa minyak atsiri buah pala mampu menghambat pertumbuhan Staphylococcus aureus pada konsentrasi 3,125\% dengan zona hambat sebesar 16,81mm (Rastuti et al., 2013). Selanjutnya, hasil penelitian Huda et al (2018); Widiastuti et al (2018); Meilina et al (2018); dan Haerazi et al (2014) menunjukkan bahwa ekstrak bunga cengkih jahe, kulit manggis dan kencur juga mampu menghambat pertumbuhan Staphylococcus aureus. Menurut Widiastuti et al (2018), aktivitas antibakteri tersebut terbentuk karena adanya senyawa bioaktif dalam ekstrak. Hasil penelitian-penelitian diatas berbanding terbalik dengan hasil penelitian ini, dimana hasil penelitian ini menunjukkan tidak adanya aktivitas antibakteri dari minyak seith.

Pada Tabel II menunjukkan bahwa nilai F hitung untuk zona hambat terhadap Staphylococcus aureus ialah sebesar 10,0 mm dengan probabilitas F sebesar 0,000 ( $\operatorname{sig}<0,05)$.

Berdasarkan uji homogenitas varian data, menunjukkan bahwa varian data dalam penelitian ini homogen $(p=0,000)$ dapat dilihat pada Tabel III.

Berdasarkan varian data penelitian yang bersifat homogen maka dilanjutkan dengan analisis post hoc test Bonferroni. Hasil uji statistik menggunakan one-way ANOVA pada taraf kepercayaan 95\% menunjukkan nilai $p=0,000$. Hal ini mengindikasikan bahwa pemberian ekstrak daun katang-katang berpengaruh secara signifikan dalam menghambat pertumbuhan Staphylococcus aureus dibandingkan dengan baik kontrol maupun minyak seith dilihat dari analisis data dari rerata diameter zona hambat. Hal ini dapat dikaitkan dengan senyawa bioaktif yang terkandung dalam ekstrak daun katang-katang yang berpotensi sebagai agen antibakteri.

\section{KESIMPULAN}

Ekstrak daun katang-katang (Ipomoea pes-caprae L.) memiliki kemampuan dalam menghambat pertumbuhan Staphylococcus aureus sedangkan minyak seith tidak memiliki kemampuan dalam menghambat pertumbuhan Staphylococcus aureus. Konsentrasi paling efektif dari ekstrak daun katang-katang ialah $100 \%$ dengan zona hambat sebesar $12 \mathrm{~mm}$ yang termasuk dalam kategori kuat dan diikuti oleh konsentrasi $80 \%$ dengan zona hambat sebesar 7,66 mm yang termasuk dalam kategori sedang.

\section{DAFTAR PUSTAKA}

Afifurrahman, Samadin, KH., \& Aziz, S. (2014). Pola Kepekaan Bakteri Staphylococcus aureus terhadap Antibiotik Vancomycin. 
Fakultas Kedokteran Universitas Sriwijaya, (4), 266-270.

Andayani, D., \& Nugrahani, R. (2018). Skrining Fitokimia dan Aktivitas Antioksidan Ekstrak Etanol Daun Katang-Katang (Ipomoea Pescaprae. L) dari Pulau Lombok Nusa Tenggara Barat. JPSCR: Journal of Pharmaceutical Science and Clinical Research, 3(2), 76.

Ariyani, F., Setiawan, L. E., \& Soetaredjo, F. E. (2017). Ekstraksi Minyak Atsiri Dari Tanaman Sereh Dengan Menggunakan Pelarut Metanol, Aseton, dan N-Heksana. Journal Widya Mandala, 7(1), 124-130.

Aziz, F., Budi Lestari, F., Nuraidah, S., Purwati, E., \& Isrina, S. (2016). Deteksi Gen Penyandi Sifat Resistensi Metisilin, Penisilin dan Tetrasiklin pada Isolat Staphylococcus aureus Asal Susu Mastitis Subklinis Sapi Perah. Jurnal Sain Veteriner, 36(1).

Bramantio, R. G. (2018). Uji Efektivitas Antibakteri Minyak Atsiri Daun Sirih Merah (Piper crocatum Ruiz \& Pav.) Terhadap Staphylococcus epidermidis secara in vitro. In Skripsi. Surakarta.

Fatisa, Y. (2013). Daya Antibakteri Ekstrak Kulit dan Biji Buah Pulasan (Nephelium mutabile) Terhadap Staphylococcus aureus dan Escherichia coli secara in vitro. Jurnal Peternakan, 10(1), 31-38. Retrieved from https://media.neliti.com/media/publica tions/127184-ID-none.pdf

Finnah, A, Pineiro, S., Reuss, R., \& Sanders, P. (n.d.). Ampicillin. Retrieved from http://www.fao.org/3/ca3711en/ca371 1en.pdf

Hafizah, I. (2014). Uji Daya Hambat Ekstrak Daun Tapak Kuda ( Ipomoea pes caprae (L)R.Br.) terhadap Staphylococcus aureus. Jurnal Medula 2(1), 91-96.

Hidayat, S., Khotimah, S., \& Armyanti, I. (2015). Uji Aktivitas Antibakteri Infusa Daun Mangga Bacang (Mangifera foetida L.) Terhadap Staphylococcus aureus secara In Vitro. Jurnal Mahasiswa Fakultas Kedokteran Untan, 3(1). Retrieved from http://jurnal.untan.ac.id/index.php/jfk/ article/view/14627

Huda, M., Rodhiansyah, \& Ningsih, D. S. (2018). Efektivitas Ekstrak Bunga Cengkeh (Eugenia aromatica) Terhadap Pertumbuhan Bakteri Staphylococcus aureus. Analis Kesehatan, 7(1).
Laboratorium Kimia Dasar Jurusan Kimia Fakultas Matematika dan Ilmu Pengetahuan Alam Universitas Pattimura Ambon. (2019). Proses Pembuatan Ekstrak Daun Katang-Katang Dengan Metode Maserasi. Ambon.

Nisfiyanti, Y. (2012). Sistem Pengobatan Tradisional (Studi Kasus di Desa Juntinyuat, Kecamatan Juntinyuat, Kabupaten Indramayu). Patanjala : Jurnal Penelitian Sejarah Dan Budaya, 4(1), 125.

Nugraheni, K. S., Khasanah, L. U., Utami, R., \& Ananditho, B. K. (2016). Pengaruh Perlakuan Pendahuluan Dan Variasi Metode Destilasi Terhadap Karakteristik Mutu Minyak Atsiri Daun Kayu Manis ( $C$. Burmanii). Jurnal Teknologi Hasil Pertanian, $I X(2), 51-64$.

Pacifici, G. M. (2017). Clinical Pharmacology of Ampicillin in Neonates and Infants: Effects and Pharmacokinetics. Int $J$ Pediatr, 5(48), 12.

Patel, J. B., Eliopoulos, G. M., Jenkins, S. G., James Lewis II, F. S., Brandi Limbago, P., Nicolau, D. P., ... Pranita Tamma, Mms. D. (2019). Performance Standards for Antimicrobial Susceptibility Testing (29th ed., Vol. 39). Retrieved from https://clsi.org/media/2663/m100ed29 _sample.pdf

Rastuti, U., Widyaningsih, S., Kartika, D., \& Ningsih, D. R. (2013). Aktivitas Antibakteri Minyak Atsiri Daun Pala Dari Banyumas Terhadap Staphylococcus aureus dan Escherichia coli Serta Identifikasi Senyawa Penyusunnya. Jurnal Ilmiah Kimia Molekul, 8(2), 197202. Retrieved from https://ojs.jmolekul.com/ojs/index.php/ jm/article/view/142/136

Repi, N. B., Mambo, C., \& Wuisan, J. (2016). Uji Efek Antibakteri Ekstrak Kulit Kayu Manis (Cinnamomum burmannii) Terhadap Escherichia coli dan Streptococcus pyogenes. Jurnal EBiomedik (EBm), 4(1).

Rumopa, P. M. E., Awaloei, H., \& Mambo, C. (2016). Uji Daya Hambat Ekstrak Biji Pala (Myristicae fragrans) Terhadap Pertumbuhan Bakteri Staphylococcus aureus dan Streptococcus pyogenes. Jurnal E-Biomedik (EBm), 4(2), 2-6.

Saraung, V., Yamlean, P. V. and, \& Citraningtyas, G. (2018). Pengaruh Konsentrasi Basis 
Gel Ekstrak Etanol Daun Tapak Kuda (Ipomoea pes-caprae (L.) R.Br.) Terhadap Aktivitas Antibakteri Pada Staphylococcus aureus. 7(3), 249-256.

Toy, T., Lampus, B., \& Hutagalung, B. (2015). Uji Daya Hambat Ekstrak Rumput Laut (Gracilaria $S p$ ) Terhadap Pertumbuhan Bakteri Staphylococcus aureus. Jurnal EGiGi, 3(1), 153-159.

Triana, D. (2014). Frekuensi $\beta$-Lactamase Hasil Staphylococcus aureus Secara Iodometri
Di Laboratorium Mikrobiologi Fakultas Kedokteran Universitas Andalas. Jurnal Gradien, 10(2). Retrieved from https://ejournal.unib.ac.id/index.php/gr adien/article/view/298effects of a selective inhibitor of lactate dehydrogenase. Exp Parasitol 111(2):105-14.

https://pubmed.ncbi.nlm.nih.gov/16098 967/ 